\title{
Analiza wybranych parametrów audiometrycznych przesiewowych badań słuchu wykonywanych w szkołach
}

\section{Analysis of the parameters of audiometric screening tests conducted in schools}

\author{
Anna Piotrowska ${ }^{1}$, Anna Zapert ${ }^{1}$, Krzysztof Tarczyński ${ }^{1}$, Krzysztof Kochanek $^{2}$ \\ ${ }^{1}$ Instytut Fizjologii i Patologii Słuchu, Światowe Centrum Słuchu, Zakład Epidemiologii i Badań Przesiewowych, \\ Warszawa/Kajetany \\ ${ }^{2}$ Instytut Fizjologii i Patologii Słuchu, Światowe Centrum Słuchu, Warszawa/Kajetany
}

Adres autora: Anna Piotrowska, Światowe Centrum Słuchu, Zakład Epidemiologii i Badań Przesiewowych, ul. Mokra 17, Kajetany, 05-830 Nadarzyn, e-mail: a.piotrowska@ifps.org.pl

\section{Streszczenie}

Cel: Celem pracy jest analiza dwóch parametrów procesu przeprowadzania audiometrycznych badań przesiewowych słuchu u dzieci klas I i VI ze szkół podstawowych na terenie m.st. Warszawy.

Materiał i metoda: Analizie poddano 38287 wyników audiometrycznego badania słuchu wykonanego u dzieci w wieku 6 i 12 lat, uczniów klas I i VI warszawskich szkół podstawowych w roku szkolnym 2011/2012 (n=20 482) i 2012/2013 (n=17 805). U wszystkich dzieci przeprowadzono audiometryczne badanie słuchu dla tonów o częstotliwościach: 0,$5 ; 1 ; 2 ; 4 ; 8 \mathrm{kHz}$. Badania wykonywano na urządzeniu do badań przesiewowych - Platformie Badań Zmysłów (PBZ). Analizie poddano dwa parametry procesu przeprowadzania badań przesiewowych słuchu: czas oraz jakość.

Wyniki: W badanej grupie średni czas jednego pomiaru wyniósł 5 min 9 s. Najkrótszy zarejestrowany czas jednego badania wyniósł $11 \mathrm{~s}$, a najdłuższy $45 \mathrm{~min} 52 \mathrm{~s}$. Najwięcej pomiarów wykonano w czasie $4 \mathrm{~min} 20 \mathrm{~s}$. Jako miernika jakości użyto odsetka wyników dodatnich uzyskiwanych przez poszczególnych badaczy obliczanego dla każdego tygodnia wykonywania badań; odsetek ten zawierał się w przedziale od $0 \%$ do $62,6 \%$.

Wnioski: Podczas realizacji programu badań słuchu w szkołach niezbędna jest systematyczna kontrola wykonywanych pomiarów, która umożliwia uzyskanie zadowalającej wiarygodności badań audiometrycznych.

Słowa kluczowe: badania przesiewowe słuchu • audiometria tonalna $\bullet$ niedosłuch $\bullet$ dzieci szkolne

Abstract

Aim: The aim of this study is to analyze two parameters of the process of conducting audiometric screening tests in children from the $1^{\text {st }}$ and $4^{\text {th }}$ grades of primary schools located in Warsaw.

Material and methods: Analysis was performed on 38.287 results of audiometric screening examinations performed in 6 and 12 -year-old children, attending the $1^{\text {st }}$ or $4^{\text {th }}$ grade of a primary school in Warsaw, in the school years 2011/2012 $(\mathrm{n}=20.482)$ and 2012/2013 $(\mathrm{n}=17.805)$. All children underwent tone audiometry hearing examination in frequencies $0.5,1,2,4 \mathrm{and} 8 \mathrm{kHz}$. Tests were performed using the screening device - Sense Examination Platform. The analysis targeted two parameters of the hearing screening process: time and quality.

Results: In the study group the mean duration of single measurement was $5 \mathrm{~min} 9 \mathrm{sec}$. The shortest registered duration of the measurement was $11 \mathrm{sec}$, the longest - $45 \mathrm{~min} 52 \mathrm{sec}$. Most measurements were performed in 4 min $20 \mathrm{sec}$. Rate of positive results for each working week of examiners was between 0 and $62.6 \%$.

Conclusions: When implementing a hearing screening program in schools it is necessary to systematically inspect the measurements performed in order to achieve the satisfactory reliability of audiometric examinations.

Keywords: hearing screening $\bullet$ pure tone audiometry $\bullet$ hearing loss $\bullet$ school children 


\section{Wstęp}

Badania przesiewowe słuchu uznawane są za działania profilaktyczne, które przeciwdziałają ujemnym konsekwencjom zaburzeń słuchu. Wczesne wykrycie i wdrożenie właściwego leczenia zaburzeń słuchu u dzieci w wieku noworodkowym, ale również przedszkolnym i szkolnym, stwarza dziecku szanse na prawidłowy rozwój oraz normalne funkcjonowanie w społeczeństwie. Dostrzeganie wagi programów przesiewowych nacelowanych na te grupy wiekowe potwierdza m.in. fakt podpisania europejskich konsensusów dotyczących badań przesiewowych słuchu, wzroku i mowy przez europejskie towarzystwa audiologiczne, okulistyczne i logopedyczne $[1,2]$.

Jednym z podstawowych założeń wszystkich programów przesiewowych jest wysoki odsetek populacji objętej badaniami. Bezspornie, badania przesiewowe należy planować w taki sposób, aby możliwe było przebadanie prawie $100 \%$ populacji docelowej. W przypadku programu badań przesiewowych słuchu noworodków w krajach, w których zdecydowana większość dzieci rodzi się na oddziałach położniczo-ginekologicznych, optymalnym miejscem do przeprowadzenia badań w populacji docelowej są oddziały noworodkowe. Taka sytuacja występuje w Polsce, gdzie aktualnie odsetek noworodków objętych badaniami przesiewowymi słuchu jest bliski 100\% [3]. W przypadku programu badań przesiewowych słuchu u dzieci w wieku szkolnym miejscem umożliwiającym przebadanie prawie całej populacji docelowej jest szkoła.

Aktualnie w badaniach przesiewowych słuchu u dzieci w wieku szkolnym najczęściej stosuje się metody audiometryczne [4]. Wyniki tych badań dostarczają informacji o sprawności układu słuchowego dziecka i oparte są zazwyczaj na ocenie reakcji słuchowych dla tonów o różnych częstotliwościach. Jeśli w uchu badanym stwierdza się brak reakcji dziecka na którejkolwiek częstotliwości o określonym natężeniu, to wynik badania przesiewowego uznaje się za dodatni, czyli nieprawidłowy. Możemy więc powiedzieć, że badanie przesiewowe słuchu to ciąg uporządkowanych czynności, w efekcie których wynik osoby badanej kwalifikowany jest do jednej z dwóch kategorii: dodatni lub ujemny.

W Polsce programy badań przesiewowych słuchu u dzieci w wieku szkolnym realizowane są w ostatnich latach z inicjatywy Instytutu Fizjologii i Patologii Słuchu. Badania wykonywane są z wykorzystaniem audiometrii tonalnej dla przewodnictwa powietrznego w zakresie częstotliwości $500-8000 \mathrm{~Hz}$.

Warunki i zasady prawidłowo przeprowadzonego klinicznego, diagnostycznego audiometrycznego badania progowego, opisane są szczegółowo w literaturze $[5,6]$. Wytyczne i standardy tego procesu odwołują się do przyjętych norm i specyfikacji i opisują m.in. parametry urządzeń (audiometr, słuchawki, kabiny), kalibrację, metodologię pomiaru, warunki akustyczne pomieszczenia do badań itp. [7].

Warunki, w których prowadzone są badania przesiewowe słuchu metodą audiometryczną w szkole, różnią się od warunków określonych w normach (tzw. gold standard), dlatego w czasie realizacji programu badań przesiewowych krytyczna jest kontrola procesu wykonywania pomiaru słuchu. Kontrola ta ukierunkowana jest na optymalizację tego procesu w zakresie wybranych parametrów, tak aby zapewnić skuteczność i efektywność całego programu.

Do najważniejszych parametrów procesu wykonywania badania przesiewowego słuchu metodą audiometryczną zaliczamy czas (t) tego procesu i jego jakość (q). Znaczenie tych parametrów wynika z konieczności wykonania, w określonym terminie, znacznej liczby badań (t), których jakość powinna zapewnić odpowiednią czułość i specyficzność przesiewu (q).

Tabela 1. Charakterystyka badanej grupy dzieci - uczniów klas I i VI warszawskich szkół podstawowych w roku szkolnym 2011/2012 oraz 2012/2013

Table 1. Characteristic of the group - children from the $1^{\text {st }}$ and $6^{\text {th }}$ grades of primary schools located in Warsaw in the school years 2011/2012 and 2012/2013

\begin{tabular}{|c|c|c|}
\hline Liczba uczniów & \multicolumn{2}{|c|}{47490} \\
\hline Liczba uczniów zbadanych & \multicolumn{2}{|c|}{38287} \\
\hline Frekwencja [\%] & \multicolumn{2}{|c|}{$80,6 \%$} \\
\hline \multirow{5}{*}{ Liczba i odsetek zbadanych uczniów klasy I } & \multicolumn{2}{|c|}{22427} \\
\hline & \multicolumn{2}{|c|}{$58,6 \%$} \\
\hline & Dziewczynki & Chłopcy \\
\hline & 11163 & 11264 \\
\hline & $49,8 \%$ & $50,2 \%$ \\
\hline \multirow{5}{*}{ Liczba i odsetek zbadanych uczniów klasy VI } & \multicolumn{2}{|c|}{15860} \\
\hline & \multicolumn{2}{|c|}{$41,4 \%$} \\
\hline & Dziewczynki & Chłopcy \\
\hline & 8112 & 7748 \\
\hline & $51,1 \%$ & $48,9 \%$ \\
\hline
\end{tabular}




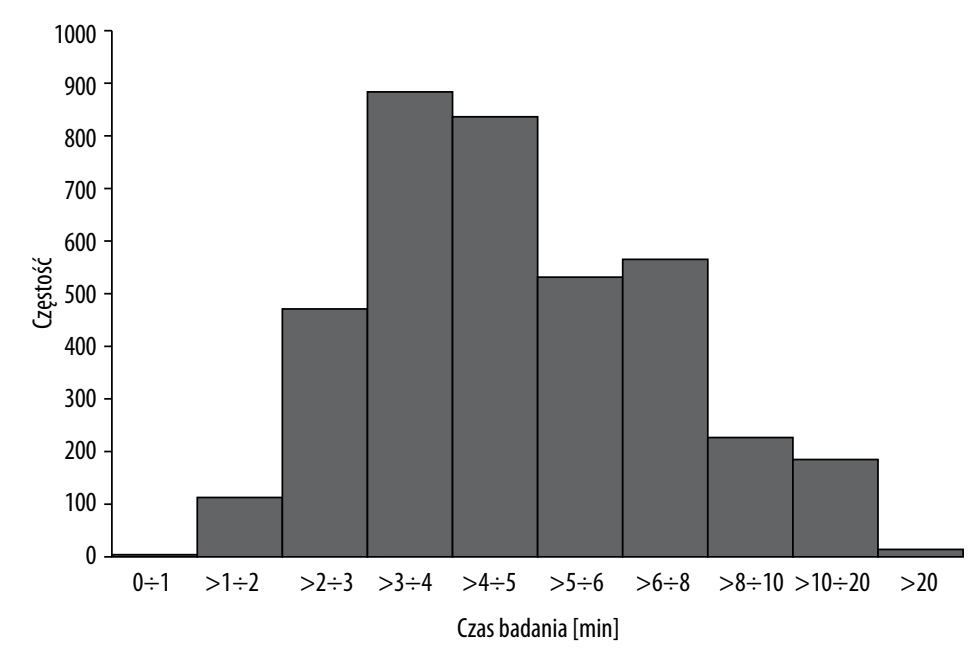

Rycina. 1. Histogram czasu trwania audiometrycznego badania przesiewowego słuchu $(n=38287)$

Figure 1. Histogram of the audiometric screening test duration $(n=38287)$

Celem pracy była analiza dwóch parametrów procesu przeprowadzania audiometrycznych badań przesiewowych słuchu u dzieci klas I i VI ze szkół podstawowych na terenie m.st. Warszawy: czasu trwania jednego pomiaru oraz jakości wykonywania badań.

\section{Material i metoda}

Audiometryczne badania przesiewowe słuchu wykonano u uczniów klas I i VI warszawskich szkół podstawowych w roku szkolnym 2011/2012 ( $\mathrm{n}=20$ 482; 172 szkoły) i 2012/2013 ( $n=17$ 805; 173 szkoły). Przebadano łącznie 38287 dzieci. Charakterystyka badanej grupy przedstawiona została $\mathrm{w}$ tabeli 1 . Badania realizowane były z udziałem przeszkolonych badaczy na terenie szkoły, w wydzielonych cichych pomieszczeniach, które zapewniały właściwe warunki akustyczne. U każdego dziecka, którego rodzice wyrazili zgodę na badanie, uzupełniono ankietę audiologiczną oraz wykonano przesiewowe audiometryczne badanie słuchu prawego i lewego ucha, dla tonów o częstotliwościach: 500, 1000, 2000, 4000 i 8000 Hz. Pomiary wykonywano metodą zstępującą, z wartością kroku $5 \mathrm{~dB}$. Za próg słyszenia przyjęto najniższe natężenie tonu, przy którym uzyskano ponad 50\% odpowiedzi, zgodnie $\mathrm{z}$ regułą: uzyskanie dwóch lub trzech jednakowych wartości progów słyszenia dla danej częstotliwości w trzech lub pięciu próbach, odpowiednio. Wynik badania określano jako prawidłowy, jeżeli próg słyszenia dla wszystkich mierzonych częstotliwości nie przekraczał $20 \mathrm{~dB}$ HL.

Badania wykonywano na urządzeniu do badań przesiewowych - Platformie Badań Zmysłów (PBZ). PBZ jest przenośnym audiometrem zakwalifikowanym wg normy PN-EN 60645-1 jako audiometr klasy IV. Urządzenie składa się z komputera typu netbook, słuchawek audiometrycznych oraz przycisku pacjenta. Platforma umożliwia przesyłanie, za pośrednictwem Internetu, wyników badań do systemu centralnego - Platformy Badań Przesiewowych (PBP), który umożliwia zarządzanie programem oraz bieżący nadzór nad jakością i liczbą wykonanych badań.

Analizę wyników badań oraz wybranych parametrów procesu przeprowadzono $\mathrm{z}$ wykorzystaniem Platformy Badań Zmysłów (PBZ) oraz Bazy Wiedzy, które stanowią integralne części Zintegrowanego Systemu Operacyjnego
„SZOK”. PBZ umożliwia automatyczne rejestrowanie oraz przesyłanie danych o dacie i godzinie rozpoczęcia badania oraz całkowitym czasie trwania każdego pomiaru. Jako miernik czasu procesu (t) użyto czas wykonania pomiaru mierzony w sekundach od rozpoczęcia pomiaru do jego zakończenia. Kryterium minimalnego czasu prawidłowo przeprowadzonego badania przesiewowego wyznaczono na podstawie analizy czasów badań wykonanych przez pięciu doświadczonych techników audiometrystów, zgodnie z przyjętą procedurą, u 10 osób prawidłowo słyszących. Jako minimalny czas trwania pomiaru przyjęto 72 sekundy. Czas maksymalny obliczono, wykorzystując górną granicę zakresu wartości nieodstających, tj. wartości równej 1,5×IQR (IQR - odstęp między kwartylem górnym i dolnym) dla wszystkich badań wykonanych w czasie nie krótszym niż $72 \mathrm{~s}$.

Jako miernika jakości (q) użyto odsetka wyników dodatnich uzyskiwanych przez poszczególnych badaczy obliczanego dla każdego tygodnia wykonywania badań, mając na uwadze fakt, że o wysokiej jakości badania świadczy niski odsetek wyników fałszywych. Nadmiernie wysoki odsetek wyników fałszywie dodatnich zmniejsza swoistość pomiaru oraz wartość predykcji dodatniej, a tym samym obniża jakość badania. Przyjęto, że odsetek wyników dodatnich nie powinien przekraczać górnej granicy wartości nieodstających. Górną granicę zakresu wartości nieodstających przyjęto jako wartość graniczną dla prawidłowo wykonanego badania przesiewowego, gdyż istnieje duże prawdopodobieństwo, iż obserwacje, które nie zawierają się w tym przedziale, tzn. nietypowo długi czas badania lub nietypowo wysoki odsetek wyników dodatnich, mogą być wynikiem nieprawidłowo przeprowadzonego pomiaru.

\section{Wyniki}

\section{Analiza czasu trwania pomiaru}

Analizę czasu trwania pojedynczego pomiaru przeprowadzono w odniesieniu do 38287 badań, wykonanych przez 54 badaczy (rycina 1).

Najkrótszy czas jednego badania wynosił 11 sekund, najdłuższe badanie trwało 45 minut 52 sekundy. Średni czas jednego pomiaru wyniósł 5 minut 9 sekund, mediana 


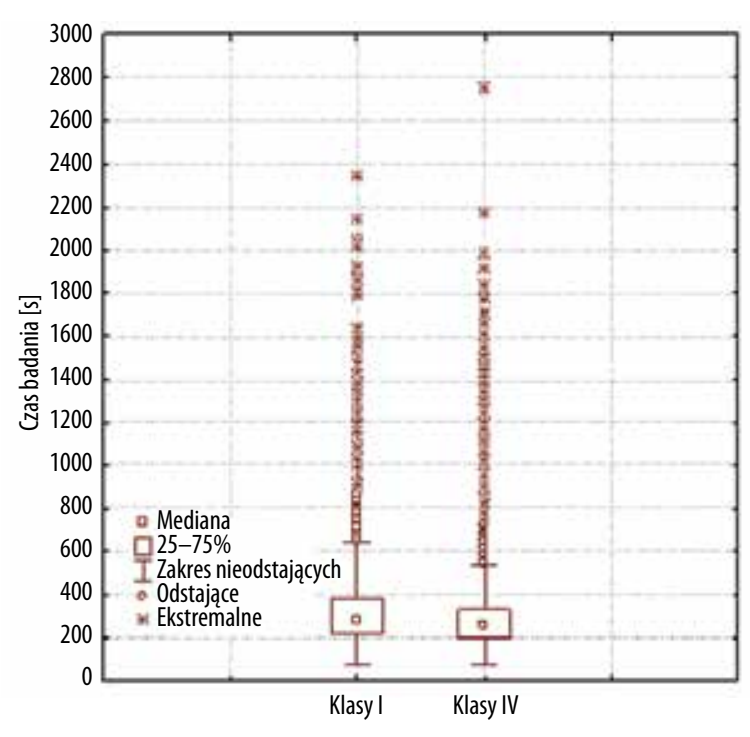

Rycina 2. Wartości mediany, rozstępu międzykwartylowego oraz zakresu wartości nieodstających i nietypowych (odstających i ekstremalnych) czasu trwania audiometrycznych przesiewowych badań słuchu trwających dłużej niż 72 s u uczniów klas I ( $n=22$ 427) oraz klas VI $(n=15860)$

Figure 2. Median, interquartile range and outliers of the audiometric screening test duration (measurements longer than $72 \mathrm{sec}$ ) - children from the $1^{\text {st }}$ and $6^{\text {th }}$ grades

4 minuty 30 sekund. Najwięcej pomiarów ( $\mathrm{n}=991)$ wykonano w czasie 4 minuty 20 sekund. $25 \%$ badań wykonano w czasie krótszym niż 3 minuty 27 sekundy $\left(Q_{1}=3\right.$ min $27 \mathrm{~s}), 25 \%$ badań w czasie dłuższym niż 6 minut 5 sekund $\left(\mathrm{Q}_{3}=6 \min 5 \mathrm{~s}\right)$ (rycina 2 ).

W czasie nie krótszym niż 72 sekundy wykonano 38015 badań (99,3\%), z czego 22279 badań (58,6\%) u dzieci z klas I, $15736(41,4 \%)$ u dzieci z klas VI. Analiza czasu badań dzieci z klas I i VI nie wykazała istotnych statystycznie różnic międzygrupowych. Obserwowano natomiast tendencję w kierunku krótszego średniego czasu trwania jednego badania $\mathrm{u}$ dzieci starszych $\left(\mathrm{t}_{\mathrm{sr}}\right.$ dzieci młodsze 5 min $45 \mathrm{~s}, \mathrm{t}_{\mathrm{sr}}$ dzieci starsze $-4 \min 79 \mathrm{~s}$ ).

U 1162 dzieci z klas I oraz 771 dzieci z klas VI czas badania przekraczał zakres wartości nieodstających (znajdujące się w odległości 1,5 IQR powyżej 75 percentyla), z czego wartości ekstremalne (znajdujące się w odległości $3 \mathrm{IQR}$ powyżej 75 percentyla) stanowiły 1,56\% i 1,69\% odpowiednio w grupie dzieci młodszych i starszych (rycina 2).

\section{Analiza jakości pomiarów}

W ciągu dwóch lat realizacji programu badania wykonywało łącznie 37 badaczy. Odsetek wyników dodatnich liczony dla każdego tygodnia pracy badaczy zawierał się w przedziale od $0 \%$ do $77,8 \%$ (wartość średnia - 11,0\%, mediana-9,5\%). Górna wartość zakresu nieodstających wyniosła 28,6\%. Częstość wyników dodatnich odpowiadającą wartościom odstającym lub ekstremalnym zarejestrowano u 9 badaczy, łącznie dla 10 tygodni wykonywania badań (rycina 3 ).

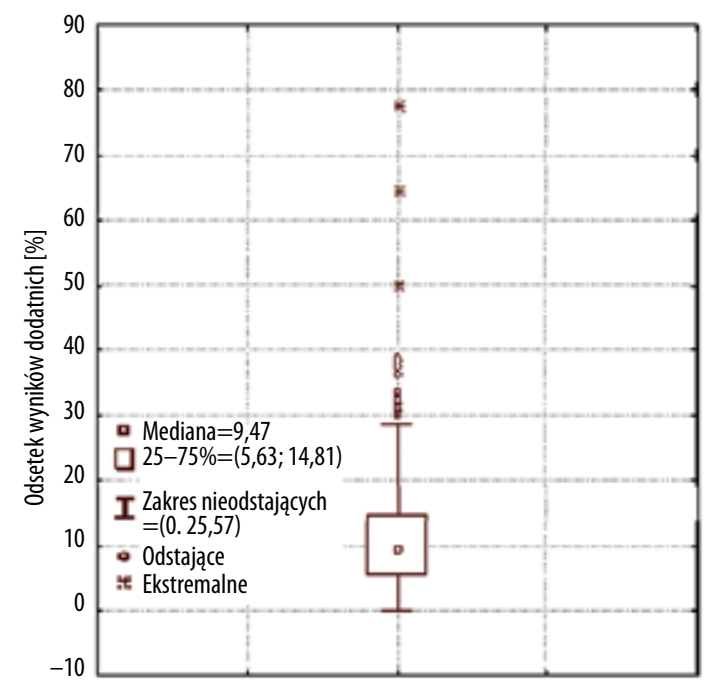

Rycina 3. Średni odsetek wyników dodatnich (mediana, rozstęp międzykwartylowy oraz zakres wartości nieodstających i nietypowych) w czasie realizacji programu w roku szkolnym 2011/2012 oraz 2012/2013

Figure 3. Average rate of positive results (median, interquatile range and outliers) during the hearing screening programs in the school years 2011/2012 and 2012/2013

\section{Dyskusja}

Audiometryczne badania słuchu u dzieci w wieku szkolnym organizowane są w Polsce od kilku lat jako programy o zasięgu krajowym lub lokalnym. Koordynatorem tych badań jest Instytut Fizjologii i Patologii Słuchu, który sprawuje nadzór zarówno merytoryczny, jak i organizacyjny nad realizacją programu. Wykonywanie badań słuchu na terenie szkoły wymaga m.in. zatrudnienia i przeszkolenia grupy osób (badaczy), które w momencie rekrutacji najczęściej nie mają doświadczenia w zakresie wykonywania badań audiometrycznych. Po odbyciu szkolenia badacze uzyskują teoretyczną wiedzę o procedurze progowego badania słuchu. Dopełnieniem szkolenia teoretycznego są zajęcia praktyczne.

Aby umożliwić systematyczną kontrolę procesu wykonywania badań przesiewowych w poszczególnych szkołach, badacze zobowiązani są do codziennego przesyłania wyników za pośrednictwem Internetu do centralnej bazy danych. Prowadzenie przez koordynatora programu bieżącej kontroli wybranych parametrów tego procesu jest jednym z elementów zarządzania programem.

Istotnym parametrem procesu wykonywania badania przesiewowego jest czas trwania tego badania. Wiadomo bowiem, iż z jednej strony, z uwagi na fakt, że badania przesiewowe mają charakter masowy i są realizowane w określonym interwale czasowym, pomiar ten nie może trwać zbyt długo, ale z drugiej strony, pomiar wykonany w zbyt krótkim czasie może świadczyć o nieprzestrzeganiu procedury badania.

Zgodnie z przyjętym kryterium minimalnego czasu prawidłowo przeprowadzonego badania przesiewowego słuchu 
wszystkie badania wykonane w czasie krótszym niż 72 sekundy uznano za wykonane niezgodnie z procedurą lub za badania niekompletne $(n=128)$; wyników tych badań nie uwzględniano w raporcie do szkół. W większości przypadków badacze zgłaszali brak współpracy dziecka jako przyczynę nieprawidłowego wykonania badania. $\mathrm{W}$ tej grupie zdarzały się jednak nieliczne przypadki wykonania badań niezgodnie $z$ procedurą. Takie przypadki wyjaśniano na bieżąco z badaczem. Jeśli była taka możliwość, badania zostały powtórzone. Dodatkowej kontroli poddano również badania, których czas przekraczał zakres wartości nieodstających, tj. takie, które trwały dłużej niż 11 minut u dzieci młodszych $(\mathrm{n}=1162)$ i 9 minut $\mathrm{u}$ dzieci starszych $(\mathrm{n}=771)$. Wykazano, że były to głównie badania, w których kontakt z dziećmi był utrudniony i pomimo podejmowanych kolejnych prób dzieci nie potrafiły skupić uwagi - w takich sytuacjach odstępowano od powtarzania badania. W kilku przypadkach badanie było wydłużone z powodu przerwy międzylekcyjnej, podczas której musiało ono zostać przerwane. W czasie nieprzekraczającym przyjętych wartości wykonano łącznie 95\% badań.

Pomiar częstości wyników dodatnich uzyskiwanych przez badaczy może być wykorzystywany jako miernik jakości procesu badań słuchu wykonywanych w szkołach. Nadmiernie wysoki, u dzieci ze szkół masowych, odsetek wyników dodatnich, którego wartość znacznie przekracza średnie dla populacji, powinien zwracać uwagę osób kontrolujących jakość procesu, gdyż prowadzi to do wzrostu wyników fałszywych. Bieżąca kontrola częstości wyników dodatnich była prowadzona w kolejnych tygodniach realizacji programu indywidualnie dla każdego badacza. Należy podkreślić fakt, że pierwszy tydzień programu nie jest pierwszym tygodniem rozpoczynania badań przez wszystkich badaczy. Natomiast pierwszy tydzień badań każdego badacza jest traktowany w sposób szczególny, z uwagi na fakt, że jest to czas nabierania doświadczenia. W przypadku stwierdzenia u danego badacza nadmiernie wysokiego (przekraczającego zakres wartości nieodstających) odsetka wyników dodatnich kontrolowano jego pracę, w celu zweryfikowania i poprawienia ewentualnych błędów popełnianych podczas wykonywania badań. $\mathrm{Na}$ tej podstawie do kontroli zakwalifikowano 9 badaczy, u których odnotowano nadmiernie wysoki odsetek wyników dodatnich w wybranych tygodniach ich pracy. W przypadku 5 badaczy (6 tygodni badań łącznie) odstąpiono od weryfikacji uzyskanych wyników, z uwagi na fakt, że wysoki odsetek wynikał $\mathrm{z}$ małej liczby badań, tj. w wybranym tygodniu badacz wykonał mniej niż 10 badań. W pozostałych przypadkach, u 4 badaczy, wysoki odsetek wyników dodatnich odnotowano $\mathrm{w}$ pierwszym tygodniu badań. Odsetek ten wynosił odpowiednio $64,9 \%$ (42/65), 36\% (8/22), $31,9 \%$ (15/47), 31,6\% (5/16) dla każdego z badaczy. Przeprowadzona w szkole kontrola pokazała, że osoby te wykonywały badania niezgodnie z przyjętą procedurą. Jeden $\mathrm{z}$ badaczy zrezygnował $\mathrm{z}$ dalszego udziału w programie. Pozostali badacze, po przeprowadzonym doszkoleniu i ponownej weryfikacji umiejętności praktycznych, w kolejnych tygodniach uzyskiwali odsetek wyników dodatnich na poziomie $<28 \%$.

\section{Podsumowanie i wnioski}

Podczas realizacji programu audiometrycznych badań słuchu w szkołach bardzo ważne jest, aby na bieżąco monitorować parametry procesu wykonywania badania, takie jak czas trwania pomiaru oraz jakość mierzona jako odsetek wyników dodatnich u każdego badacza. Każde znaczące zwiększenie odsetka wyników dodatnich oraz czas badania uniemożliwiający jego prawidłowe wykonanie powinny zwracać uwagę osób nadzorujących realizację programu, umożliwiając tym samym podejmowanie działań naprawczych (np. dodatkowe szkolenia). Systematyczna kontrola wybranych parametrów pozwala ograniczyć odsetek niewiarygodnych pomiarów.

Projekt „Program badań przesiewowych stuchu dla uczniów klas I $i$ VI szkół podstawowych na terenie m.st. Warszawy" był finansowany ze środków m.st. Warszawy.

\section{Piśmiennictwo:}

1. Skarżyński H, Piotrowska A. Screening for pre-school and school-age hearing problems: European Consensus Statement. Int J Pediatr Otorhinolaryngol, 2012; 76(1): 120-1.

2. Skarżyński H, Piotrowska A. Prevention of communication disorders - screening pre - school and school - age children for problems with hearing, vision and speech: European Consensus Statement. Med Sci Monit, 2012; 18(4): 17-21.

3. Szyfter W, Wróbel M, Radziszewska-Konopka M, Szyfter-Harris J, Karlik M. Polish universal neonatal hearing screening program - 4-year experience (2003-2006). Int J Pediatr Otorhinolaryngol, 2008; 72: 1783-7.
4. Śliwa L, Hatzopoulos S, Kochanek K, Piłka A, Senderski A, Skarżyński PH. A comparison of audiometric and objective methods in hearing screening of school children. A preliminary study. Int J Pediatr Otorhinolaryngol, 2011; 75(4): 483-8.

5. Carhart R, Jerger JF. Preferred method for clinical determination of pure-tone thresholds. J Speech Hear Disord, 1959; 24: $330-45$.

6. Gelfand SA. Hearing: An introduction to psychological and physiological acoustics. 2nd edition. New York and Basel: Marcel Dekker, Inc.; 1990.

7. American Speech-Language-Hearing Association. (2005). Guidelines for manual pure-tone threshold audiometry. Available from www.asha.org/policy/GL2005-00014/\#sthash.74BWLAy1.dpuf 